\title{
Ecological and Biological studies on Tetranychus urticae Koch on Maize single hybrids at Gharbia Governorate.
}

\author{
A.M. Metwally ${ }^{1}$, M. E. El-Naggar ${ }^{2}$; A. B. Abou-El-Sooud ${ }^{1}$ and A. I. Amer ${ }^{2}$ \\ 1-Fac. Agric. Al-Azhar Univ., Nasr City Cairo, Egypt, and 2-Plant Prot. Res. Inst., A.R.C, Dokki, Giza, Egypt.
}

\begin{abstract}
Field and laboratory studies were conducted on the two spotted spider mite Tetranychus urticae Koch throughout the year 2004-2005 at Gharbia governorate. The study included population fluctuations of T. urticae, Euseius scutalis and Pronematus ubiquitus on ten maize single hybrids (i.e. SC10, Pioneer30K8, SC122, SC123, SC124, SC129, YSC155, YSC3080, Bacheir13 and Watania4), and their relation with various meteorological variables. Susceptibility of different maize cultivars to the infestation with $T$. urticae revealed significant differences in moving stages, influence of leaf chemical components with $T$. urticae infestation was studied. The study revealed that the maize (YSC3080) single crosses recorded the highly significant susceptibility to infestation with T. urticae, recording averages of 235.21 and 274.50 moving stages/ 20 leaves, while single cross (SC10) more resistant to mite infestation recording averages 115.54 and 118.46 moving stages/ 20 leaves during the two successive years, respectively. Mite population reached its peak on maize during season 2004 in early September, while in the season 2005 it had two peaks, one in early August and the second in early in September, for all tested hybrids. Developmental times and reproduction rate of T. urticae were studied on leaves of four maize single crosses (i.e. YSC3080, Bacheir13, SC122 and SC10) at laboratory conditions of $28 \pm 2{ }^{\circ} \mathrm{C}, 65 \pm 5 \% \mathrm{RH}$ and $16: 8 \mathrm{~L}$ : D. Immature developmental time of T. urticae was longest on SC10 (6.7days) followed by yellow SC122 (5.5 days) than Bacheir13 and YSC3080 (5.1days). Longevity of $T$. urticae was 12.8, 10.4, 9.9, and 9.8 days on YSC3080, Bacheir13, SC122 and SC10, respectively. The highest net reproductive rate (Ro) was 18.79 females/ female/generation on YSC3080, and the lowest was 7.2 females/ female/ generation on SC10.
\end{abstract}

Key words: Maize, hybrids, Tetranychus urticae, Ecology, Biology.

\section{Introduction}

Maize (Zea mays L.) is the most important grain crop in Egypt and produced throughout the country under diverse environments, as it is widely distributed all over the world. The two-spotted spider mite, Tetranychus urticae Koch (Acari, Tetranychidae) is one of the most serious agricultural pests in the world. This mite attacks a wide range of vegetables, field crops, fruit trees, ornamental plants and weeds (Zaher, 1984). Heavy infestation of maize leaves by spider mites reduces plant growth and yield, reaching $47 \%$ reduction in maize yield (Bacon et al., 1962). The level of infestation depends on the temperature and humidity, and thus varies from year to year. It also depends on the plant cultivars in question (Skorupska, 2004).

Maize cultivars differ in terms of their susceptibility to spider mite infestation, highly significant difference between single crosses of maize, the single crosses 10, 122 and watania14 were resistant, while Pioneer 3080 was susceptible to spider mite infestation. In addition, significant differences between the two predatory mites Euseius scutalis (A.-H.) and Pronematus ubiquitus McGregor population, and single crosses of maize, (Azouz, 2005).

Giza 125 and Giza 162 varieties proved to be the most susceptible hybrids to spider mite infestation in white and yellow maize varieties, respectively, while Giza 129 and Giza 166 were the most tolerant in the two varieties, respectively (Mead, et al. 2010).

Several studies have indicated significant differences in susceptibility, resistance or tolerance level to $T$. urticae on crops, vegetables and fruits (Labanouska, 2007; Afifi et al., 2010; Rezaie et al., 2013). The population growth parameters of $T$. urticae such as developmental rate, survival, reproduction and longevity vary with temperature, host phonological stage and relative humidity (Liu and Tsai 1998, El-Halawany \& Abedl-wahed 2013).

The main objectives of this study were to evaluate the population fluctuations of $T$. urticae on ten maize single cross hybrids throughout the two seasons in relation to whether factors and predatory mites. In addition, the relationship between mite infestation and maize leaves chemical contents. In addition, susceptibility of four maize single cross hybrids to the infestation with $T$. urticae was studied under laboratory conditions.

\section{Material and methods}

\section{Ecological studies:}

Field experiments were carried out at the Experimental Farm of Gemmeiza Agriculture Research Station, Agricultural Research Center 
(ARC), Egypt, during 2004 and 2005 seasons at Gharbia governorate.

Ten maize single crosses hybrids (i.e. SC10, Pioneer30K8, SC122, SC123, SC124, SC129, YSC155, YSC3080, Bacheir13 and Watania4), were planted in an area of ten feddan $\left(4200 \mathrm{~m}^{2}\right)$, which was chosen and prepared for cultivation. This area was divided into 40 plots, each one (1/50 feddan). After 25 days post plantation, every 15 days, sample of 20 leaves presented for each variety. Motile stages of phytophagous and predacious mites on lower and upper surfaces of leaves were counted. Average temperatures $\left({ }^{\circ} \mathrm{C}\right)$ and average relative humidity (R.H.) prevailing in the area during the study, were recorded.

\section{Phytochemical analysis of maize leaf hybrids:}

Leaf samples of the ten maize hybrids cultivated in 2005 season, were picked up every 15 days, cleaned, washed with distilled water, and dried in an oven at $70^{\circ} \mathrm{C}$ for $48 \mathrm{~h}$., then grinded into fine powder. The total carbohydrate, total protein, nitrogen, phosphorus, calcium and potassium were estimated according to the methods of (Azouz, 2005, Mead, et al., 2010 and Afifi et al., 2013).

\section{Biological studies:}

The stock population of $T$. urticae was collected from maize (Zea mays L., Family Poaceae) in Gemmeiza Agriculture Research Station, Gharbia governorate. The stock culture was maintained on maize leaves in a rearing chamber $\left(28^{\circ} \mathrm{C}, 65 \pm 5 \%\right.$ RH. and 16:8 light (L): dark (D).

Experiments were conducted on four single crosses of maize hybrids (i.e. YSC3080, Bacheir13, SC122 and SC10). Biological aspects of T. urticae were studied $28 \pm 2{ }^{\circ} \mathrm{C}$ and $65 \pm 5 \% \mathrm{RH}$. and 16:8 L: $\mathrm{D}$ photoperiod. One leaflet from the first fully expanding leaf per plant of each variety was chosen. It was well washed with running water to remove any possible residuals or mites. Leaf discs of about 2.5$\mathrm{cm}$ in diameter were made surrounded by tangle foot, and placed lower surface up on of moisten cotton wool in Petri dishes of $12-\mathrm{cm}$ diameter, and a $T$. urticae couple (male and female) was placed on each disc, for each variety. These Petri dishes were kept for 24 hours to allow mating, thereafter, males were removed, while female served as a source for knownage eggs, and larvae. About 40 hatching larvae were kept singly to a leaf of each variety and left to continue their life span. Newly emerged females were copulated and left to deposit their eggs. Monitoring was conducted twice daily and essential records were noted. To determine sex ratio, ten newly emerged females to which males were added then placed on leaf discs and kept under the same condition of temperatures and RH. From the deposited eggs of each female, 50 eggs (25 eggs after three days and 25 eggs after one week) were left to develop until reach the adult stage, and then males and females were counted. Dishes were kept in incubators containing saturated solution of $\mathrm{NaCl}$ to maintain at $70 \% \mathrm{RH}$.

\section{Life table parameters of the two-spotted spider mite}

Females of $T$. urticae that reached the adult stage were transferred single, each single female on new leaf disc. Developmental period, mortality among different stages and oviposition by resultant females were recorded daily for each female. Life table parameters were estimated according to (Birch, 1948) using the Life48, BASIC Computer program (Abou-Setta et. al., 1986).

\section{Statistical analysis:}

Data were analyzed by one-way analysis of variance (ANOVA) and mean comparison using LSD to test the significant differences between mean values and correlation coefficient between the spider mite population and weather factors; also between mite population and chemical contents of maize leaves using SAS statistical software (SAS Institute, 2010).

\section{Results and discussion}

\section{Ecological studies:}

\section{Population fluctuation of $T$. urticae on maize varieties during 2004 and 2005 growing seasons \\ Results in Table (1) showed that, T. urticae} occurred during the two seasons from June $15^{\text {th }}$ to September $15^{\text {th }}$. During the first season, the infestation with mite moving stages occurred in few numbers after 25 days of planting date on all tested varieties. A definite trend in population fluctuation was observed, the population increased slowly until about July $1^{\text {st }}$, then it sharply increased until reached its peak during the first week of September. This result was observed by all tested maize hybrids with different degrees. After that, the number of mites decreased gradually until the end of the season. The mean numbers of moving stages of T. urticae during the first season were 115.54, 179.39, 127.82, 175.54, $172.21,189.57,191.21,235.21,172.14$ and 127.25 individuals/ 20 leaves for SC10, Pioneer30K8, SC122, SC123, SC124, SC129, YSC155, YSC3080, Bacheir13 and Watania4, respectively. 
Table 1. Population fluctuation of motile stages of Tetranychus urticae Koch, on ten maize single hybrids at Gharbia governorate during season 2004.

\begin{tabular}{|c|c|c|c|c|c|c|c|c|c|c|c|c|}
\hline \multirow[t]{2}{*}{ Hybrids } & \multicolumn{10}{|c|}{ Average number of T. urticae motile stages/ 20 leaves } & \multirow{2}{*}{$\begin{array}{l}\text { Mean } \\
\text { Temp. }\end{array}$} & \multirow{2}{*}{$\begin{array}{l}\text { Mean } \\
\text { R.H. }\end{array}$} \\
\hline & SC10 & Pioneer $30 \mathrm{~K} 8$ & SC122 & SC123 & $\mathrm{SC} 124$ & SC129 & YSC155 & YSC3080 & Bacheir13 & Watania4 & & \\
\hline 15-Jun-04 & 1.5 & 1.5 & 1.5 & 1.5 & 1.75 & 1.25 & 1.5 & 1.25 & 1.25 & 1.5 & 24.33 & 44.52 \\
\hline 01-Jul-04 & 13.25 & 29 & 11 & 26 & 28.5 & 22 & 28 & 42.5 & 31 & 11 & 27.10 & 45.38 \\
\hline 15-Jul-04 & 33 & 53 & 38.25 & 47.25 & 58 & 46.75 & 57.25 & 84 & 63.5 & 40.75 & 28.54 & 40.86 \\
\hline 1-Aug-04 & 59 & 114 & 68.25 & 102 & 88.75 & 119 & 126 & 152 & 112 & 64 & 27.95 & 45.14 \\
\hline 15-Aug-04 & 207 & 321.25 & 223.25 & 272 & 297.25 & 312 & 323.75 & 348.25 & 292 & 268.5 & 28.17 & 48.95 \\
\hline 01-Sep-04 & 268 & 401 & 299.25 & 421 & 395.75 & 436 & 413 & 605.25 & 379 & 274 & 27.62 & 46.86 \\
\hline 15-Sep-04 & 227 & 336 & 253.25 & 359 & 335.5 & 390 & 389 & 413.25 & 326.25 & 231 & 26.17 & 53.64 \\
\hline Total & 808.75 & 1255.75 & 894.75 & 1228.75 & 1205.5 & 1327 & 1338.5 & 1646.5 & 1205 & 890.75 & & \\
\hline Mean & 115.54 & 179.39 & 127.82 & 175.54 & 172.21 & 189.57 & 191.21 & 235.21 & 172.14 & 127.25 & & \\
\hline
\end{tabular}

Correlation coefficient between mean population of T. urticae motile stages

I.D. = Inspection date, $*$ Significant at $5 \%$ level.

Table 2. Population fluctuation of motile stages of Tetranychus urticae Koch, on ten maize single hybrids at Gharbia governorate during season 2005. Hybrids Average number of T. urticae motile stages/ 20 leaves

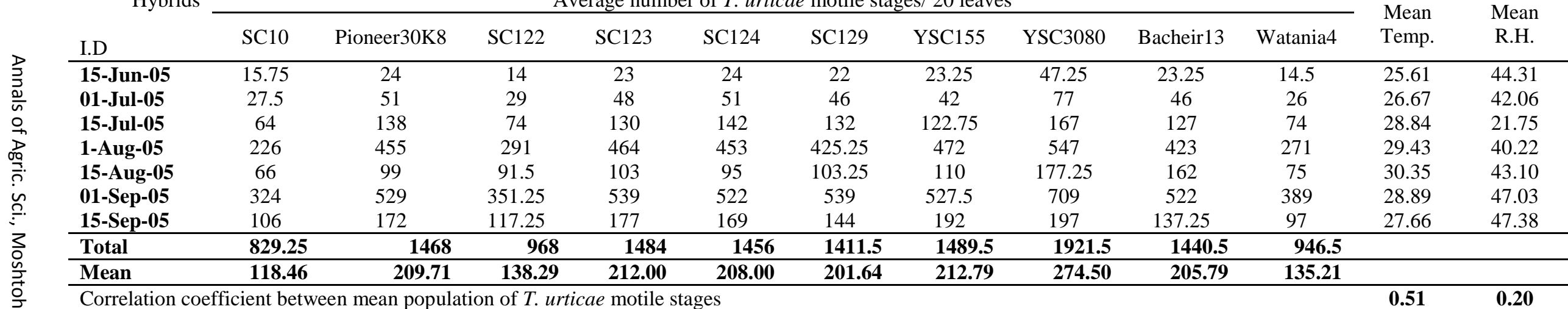

coefficient between mean population of $T$. urticae motile stages

I.D. = Inspection date, $\quad *$ Significant at $5 \%$ level. 
In the second season, the two-spotted spider mite $T$. urticae had two peaks, the first in the first week of August and the second in the first week of September on all tested hybrids (Table, 2). The twospotted spider mite was recorded with low number in the first week of June 2005, then increased in number to reach its highest population during the first week of August. After that, counts decreased from mid August and increased again in early September, then sharply decreased gradually in number until the end of the season. This result was practical by all tested maize hybrids with different degrees. The mean numbers of moving stages of $T$. urticae during the first season were 118.46, 209.71, 138.29, 212, 208, $201.64, \quad 212.79, \quad 274.50, \quad 205.79$ and 135.21 individuals/ 20 leaves for SC10, Pioneer30K8, SC122, SC123, SC124, SC129, YSC155, YSC3080, Bacheir13 and Watania4, respectively.

Population fluctuation of $T$. urticae was nonsignificantly positively correlated with temperature during the two successive seasons. However, significantly positive correlation between population density and relative humidity in the first season, but non-significanty positive in the second season (Table, 1\&2).

Similar results were observed by Margoli \& Kennedy (1984), Azouz (2005) and Mead, et al. (2010) who studied the population of T. urticae on maize hybrids.

\section{Predacious mites:}

As shown in Tables (3\&4), the seasonal fluctuation of predaceous mites associated with $T$. urticae is necessary to explain the variation in its population and their role in minimizing the rate of pest infestation. The present study revealed two species of predaceous mites namely, Euseius scutalis (A.-H.) and Pronematus ubiquitus McGregor collected together with $T$. urticae during the studying period from June $15^{\text {th }} 2004$ to September $15^{\text {th }} 2005$ on single cross hybrids.

The two predatory mites population fluctuation started in few numbers in mid July then gradually increased in number to reach its peak in early September in all single cross hybrids during the two successive seasons, then sharply decreased gradually in number until the end of the season. This result was noticed with all tested maize hybrids with different degrees. The mean numbers of moving stages of the two predatory mites, E. scutalis and $P$. ubiquitus during the first season were $5.05 \& 4.40,5 \& 4.80$, $5.35 \& 4.75,6.35 \& 4.50,6 \& 4.35,7.25 \& 4.25,7.85 \&$ $6.15, \quad 10.3 \& 8.80,6.4 \& 6.15, \quad 5.05$ and 6.20 individuals/ 20 leaves for SC10, Pioneer30K8, SC122, SC123, SC124, SC129, YSC155, YSC3080, Bacheir13 and Watania4, respectively. While these values in the second year were, $12 \& 4, \& 4.35$, $16.15 \&, 5.65 \& 15.2,5.75 \& 15.45,5.65 \& 16.55$, $4.1 \& 17.4,6.6 \& 22.55,7.2 \& 17.5,5.95 \&, 15.45$ and 4.35 individuals/ 20 leaves for SC10, Pioneer30K8,
SC122, SC123, SC124, SC129, YSC155, YSC3080, Bacheir13 and Watania4, respectively. The population of the predatory E. scutalis mite increased in the second year than in the first year on all single hybrids. Similar to the present study, Azouz (2005) reported that fluctuation in mite population of the two predatory mites on single and three crosses hybrids of maize associated with $T$. urticae and Steneotarsonemus saydi recorded its peak in early September.

The statistical analysis correlation between the mean population of the two predatory mites and mean temperatures and relative humidity were nonsignificantly positive during the two successive seasons 2004 and 2005 .

\section{Efficiency of the predacious mites on $T$. urticae population}

Statically analysis shown in Table (5) indicated positive correlation between the $T$. urticae population and the two predatory mites, E. scutalis and $P$. ubiquitus in all single hybrids in the first season 2004, but highly significant positive on single hybrid SC10. Concerning, statistical data obtained in the second season 2005 in Table (6) showed that, highly positive significance between the two-spotted spider mite population and the predatory mite $P$. ubiquitus on all single hybrids except the two single hybrids Sc124 and SC123. While positive correlation was observed between the $T$. urticae population and the two predatory mites on all single hybrids in the second year. These results mentioned that the two predatory mites, E. scutalis and $P$. ubiquitus were the main important predators for suppressing population density of $T$. urticae population during the two successive seasons. A similar result was obtained by Azouz (2005).

\section{Evaluation of the susceptibility of different maize single cross hybrids to $T$. urticae infestation and its relation with leaf phytochemical components.}

Obtained data in Table (7) indicated that, the single cross hybrid YSC3080 was the most highly significant susceptible to infestation recording 235.21 and 274.5 individuals/ 20 leaves during the two successive seasons 2004\& 2005, respectively, followed by the moderately infested hybrids yellow SC155, SC129 and Bacheir13 with mean numbers $191.21 \& 212.79,189.57 \& 201.64$ and $172.14 \& 205$, during the two successive seasons, respectively. Nonsignificant differences were recorded between the single crosses Bacher13, yellow SC155, SC129, SC123, SC124 and Pioneer 30K8 during the two seasons. Single cross hybrids, SC10, SC122 and Watania4 were the higher tolerant that gave the lowest significant difference in the number of mite infestations (115.54\&118.46, 127.82\& 138.29 and 127.25\&135.21, respectively. These results coincided with those obtained by Azouz (2005) and Mead, et al. (2010). 


\section{Phytochemical analysis of maize leaf hybrids:}

One of the most important factors which may explain the susceptibility or the tolerance of maize hybrids to the infestation by $T$. urticae is the phytochemical components of their leaves. So data tabulated in Table (8) show the mean infestation rates by movable stages of $T$. urticae to ten different maize hybrids SC10, Pioneer30K8, SC122, SC123, SC124, SC129, YSC155, YSC3080, Bacheir13 and Watania4 and the correspondent percentages or amount of their leaves content of some phytochemical components (nitrogen, phosphorus, calcium, potassium, total carbohydrate and total protein) throughout the plant growth stages during 2005 season at the experimental farm of Gemmeiza Agriculture research station (ARC), Gharbia governorate and their relation with each other.

Concerning the relation between the population levels and the previously mentioned components, the calculated correlation coefficient values were significantly positive in case of nitrogen, phosphorus, total carbohydrate, total protein as the correspondent $\mathrm{r}$ values were $0.87,0.80,0.78$ and 0.90 , respectively. On the other hand, the relation was significantly negative with calcium and potassium as (-0.89 and 0.80 ) in all single hybrids.

The highest mean number of T. urticae occurred on the leaves of YSC3080 hybrid (274.50 individuals/20 leaves) was associated with higher levels of nitrogen, phosphorus, total carbohydrate and total protein $(4.2,3.5,63.5$ and 14.5, respectively), indicating positively significant relationships with the population densities throughout the growing season. The lowest mean number of $T$. urticae on leaves of Single hybrid SC10 (118.46 individuals/ 20 leaves) was associated with lower levels of nitrogen, phosphorus, total carbohydrate and total protein $(3,2.5,50.5$ and 11 , respectively).

For both calcium and potassium, it seems that by decreasing the amount of those two components in all single hybrids, the population density on the leaves increased. Similar results agreement with that obtained by Margoli and Kennedy (1984), Labanowska (2007), Afifi et al. (2010) and Afifi et al. (2013).

\section{Biological studies:}

Obtained developmental times of various stages of $T$. urticae on four maize single cross hybrids (i.e. YSC3080, Bacheir13, SC122 and SC10) at laboratory conditions of $\left(28 \pm 2{ }^{\circ} \mathrm{C}, 75 \pm 5 \% \mathrm{RH}\right.$ and 16:8 L: D) were presented in Table (9). T. urticae females hatched after 3.2, 3.3, 3.7 and 3.9 days on YSC3080, Bacheir13, SC122 and SC10 hybrids, respectively, while males hatched after shorter periods.

Shortest developmental durations showed that females reached maturity after 8.3 days on Single cross YSC3080, while the longest duration was recorded on SC10 as 10.6 days.

Longevity of females and males followed similar trend. Longevity was longer on SC10 variety, followed by Bacheir13, SC122 and YSC3080 hybrids. Liu and Tsai (1998) studied the development of Tetranychus tumidus Banks on coconut palm at 6 constant temperatures, the developmental periods of immature stages ranged from 39.6 days at $15^{\circ} \mathrm{C}$ to 7.4 days at $30^{\circ} \mathrm{C}$.

The number of deposited eggs per female and daily rate of $T$. urticae were highest on YSC3080 hybrid as (44.8 eggs/ female and 4.6 eggs/female/ day). On the other hand, the lowest values were recorded on single crosses hybrids SC10 as (19.8 eggs/ female and 3.6 eggs/female/ day).

\section{Life table parameters of $\boldsymbol{T}$. urticae}

Results in Table (9) showed that mean generation time (T) was longest on SC10 (12.7 days) and the lowest was 9.8 days on YSC3080 hybrid. The same trend was observed for other life table parameters. The required time for population of $T$. urticae to multiply (DT) was 2.86 days on YSC3080 variety, while the longest period was 5.09 days on SC10 variety.

The maximum values of intrinsic rate of increase $\left(\mathbf{r}_{\mathrm{m}}\right)$ and the finite rate of increase $(\boldsymbol{\lambda})$ were obtained on single crosses YSC3080 (0.242 and 1.27 individuals/female/day). Minimum values were obtained on single crosses SC10. The peak net reproductive rate (Ro) occurred on YSC3080 variety as 18.79 individuals per generation; the lowest value was on SC10 hybrid as 7.2 individuals per generation. The $r_{m}$ value is an important parameter describing the growth potential of a population under different food as it reflects the overall effects of food on development, reproduction and survival rate of populations.

This result is consistent with findings from previous studies of Najafabadi (2012) who found that on biology of the two-spotted spider mite on Phaseolus vulgaris, the analysis of all life table parameters $\left(\mathbf{r}_{\mathrm{m}}, \mathrm{Ro}, \boldsymbol{\lambda}, \mathrm{T}\right.$ and DT $)$ indicated significant differences among five host plants.

El-Halawany and Abd El-wahed (2013) showed that, when reared $T$. urticae on persimmon at different temperatures, the maximum values of $\left(\mathbf{r}_{\mathbf{m}}\right)$ and $(\lambda)$ was obtained at $30^{\circ} \mathrm{C}(0.243-1.34$ O/Q $/$ day $)$ and Minimum values were obtained at $15^{\circ} \mathrm{C}$. The peak net reproductive rate (Ro) occurred at $30^{\circ} \mathrm{C}$ as 47.51 to 63.47 individuals/ $/$ /generation.

Afifi et al. (2013) studied the biology of $T$. urticae on Eggplant and showed that, the shortest mean generation was 12.08 days on Black baity cultivar, and the longest was 13.2 days on Baity cultivar. The highest (Ro) was 32 females / female / generation on Black baity and lowest was 21.13 females / female / generation on Baity cultivar. 
Table 3. Population fluctuation of the two predatory mites Euseius scutalis (A.-H.) and Pronomatus ubiquitous (McGregor), on ten maize single hybrids at Gharbia governorate during season 2004.

\begin{tabular}{|c|c|c|c|c|c|c|c|c|c|c|c|c|c|c|c|c|c|c|c|c|c|c|}
\hline \multirow[t]{2}{*}{ Hybrids } & \multicolumn{20}{|c|}{ Average number of two predatory mites / 20 leaves } & \multirow{3}{*}{$\begin{array}{c}\text { Mea } \\
\text { n } \\
\text { Tem } \\
\mathrm{p}\end{array}$} & \multirow{3}{*}{$\begin{array}{c}\text { Mea } \\
\mathrm{n} \\
\text { R.H. }\end{array}$} \\
\hline & \multicolumn{2}{|c|}{$\mathrm{SC} 10$} & \multicolumn{2}{|c|}{$\begin{array}{c}\text { Pioneer30K } \\
8 \\
\end{array}$} & \multicolumn{2}{|c|}{ SC122 } & \multicolumn{2}{|c|}{$\mathrm{SC} 123$} & \multicolumn{2}{|c|}{$\mathrm{SC} 124$} & \multicolumn{2}{|c|}{ SC129 } & \multicolumn{2}{|c|}{ YSC155 } & \multicolumn{2}{|c|}{ YSC3080 } & \multicolumn{2}{|c|}{ Bacheir13 } & \multicolumn{2}{|c|}{ Watania4 } & & \\
\hline I.D & $E$. & $P$. & $E$. & $P$. & $E$. & $P$. & $E$. & $P$. & $E$. & $P$. & $E$. & $P$. & $E$. & $P$. & $E$. & $P$. & $E$. & $P$. & $E$. & $P$. & & \\
\hline $\begin{array}{l}15 / 6 / 0 \\
4\end{array}$ & $\mathbf{0}$ & $\mathbf{0}$ & $\mathbf{0}$ & $\mathbf{0}$ & $\mathbf{0}$ & 0 & 0 & 0 & 0 & 0 & 0 & 0 & 0 & 0 & 0 & 0 & 0 & 0 & 0 & 0 & 24.33 & $\begin{array}{c}44.5 \\
2\end{array}$ \\
\hline $1 / 7 / 04$ & 0 & 0 & 0 & 0 & 0 & 0 & 0 & 0 & 0 & 0 & 0 & 0 & 0 & 0 & 0 & 0 & 0 & 0 & 0 & 0 & 27.10 & $\begin{array}{c}45.3 \\
8\end{array}$ \\
\hline $\begin{array}{l}15 / 7 / 0 \\
4\end{array}$ & 2.75 & 0 & 3.25 & 0 & 2 & 0 & 2.25 & 0 & 1.5 & 0 & 1.25 & 0 & 2 & 0 & 4.25 & 0 & 3.5 & 0 & 2 & 0 & 28.54 & 40.86 \\
\hline $1 / 8 / 04$ & 3.25 & 4.25 & 4 & 2 & 2.5 & 3 & 5.25 & 4.75 & 4 & 3.25 & 3.5 & 1.5 & 5.25 & 6.25 & 8.75 & 9.75 & 6.5 & 3.5 & 4.75 & 6.25 & 27.95 & 45.14 \\
\hline $\begin{array}{l}15 / 8 / 0 \\
4\end{array}$ & 6 & 5.25 & 4.25 & 6.5 & 6.5 & 7 & 9 & 6.5 & 5.75 & 7.75 & $\begin{array}{c}10.2 \\
5\end{array}$ & 6 & 7 & 8.5 & 13 & $\begin{array}{c}10.2 \\
5\end{array}$ & 7 & 9 & 6 & 9.5 & 28.17 & 48.95 \\
\hline $1 / 9 / 04$ & 8.25 & 7.75 & 9.5 & 9.5 & 10.5 & 8.5 & 9.5 & 7.25 & $\begin{array}{c}11.7 \\
5\end{array}$ & 6.5 & 14 & 7.75 & $\begin{array}{c}15.2 \\
5\end{array}$ & 9.75 & $\begin{array}{c}18.2 \\
5\end{array}$ & 13.5 & $\begin{array}{c}10 . \\
5\end{array}$ & $\begin{array}{c}10.2 \\
5\end{array}$ & 9 & 9.25 & 27.62 & 46.86 \\
\hline $\begin{array}{l}15 / 9 / 0 \\
4\end{array}$ & 5 & 4.75 & 4 & 6 & 5.25 & 5.25 & 5.75 & 4 & 7 & 4.25 & 7.25 & 6 & 9.75 & 6.25 & 7.25 & 10.5 & 4.5 & 8 & 3.5 & 6 & 26.17 & 53.64 \\
\hline Total & $\begin{array}{c}25.2 \\
5 \\
\end{array}$ & $\begin{array}{c}22.0 \\
0\end{array}$ & 25 & 24.00 & $\begin{array}{c}26.7 \\
5\end{array}$ & $\begin{array}{c}23.7 \\
5\end{array}$ & $\begin{array}{c}31.7 \\
5\end{array}$ & $\begin{array}{c}22.5 \\
0\end{array}$ & 30 & $\begin{array}{c}21.7 \\
5\end{array}$ & $\begin{array}{c}36.2 \\
5 \\
\end{array}$ & $\begin{array}{c}21.2 \\
5\end{array}$ & $\begin{array}{c}39.2 \\
5\end{array}$ & $\begin{array}{c}30.7 \\
5\end{array}$ & 51.5 & $\begin{array}{c}44.0 \\
0\end{array}$ & 32 & $\begin{array}{c}30.7 \\
5\end{array}$ & $\begin{array}{c}25.2 \\
5\end{array}$ & $\begin{array}{c}31.0 \\
0\end{array}$ & 24.33 & 44.52 \\
\hline Mean & $\begin{array}{l}5.05 \\
\end{array}$ & 4.40 & 5 & 4.80 & $\begin{array}{l}5.35 \\
\end{array}$ & 4.75 & 6.35 & $\begin{array}{l}4.50 \\
\end{array}$ & 6 & 4.35 & 7.25 & 4.25 & 7.85 & $\begin{array}{l}6.15 \\
\end{array}$ & 10.3 & 8.80 & 6.4 & 6.15 & 5.05 & 6.20 & 27.10 & 45.38 \\
\hline $\begin{array}{l}\text { Correlat } \\
\text { Correlat }\end{array}$ & $\begin{array}{l}\text { on coe } \\
\text { on coe }\end{array}$ & $\begin{array}{l}\text { ficient } \\
\text { ficient }\end{array}$ & $\begin{array}{l}\text { etwee } \\
\text { etwee }\end{array}$ & mean 1 & $\begin{array}{l}\text { opulat } \\
\text { opulat }\end{array}$ & $\begin{array}{l}\text { n of } \boldsymbol{I} \\
\mathrm{n} \text { of } \boldsymbol{I}\end{array}$ & $\begin{array}{l}\text { scutal } \\
\text { ubiqu }\end{array}$ & & & & & & & & & & & & & & $\begin{array}{c}0.41 \\
0.3\end{array}$ & $\begin{array}{l}0.44 \\
0.64\end{array}$ \\
\hline
\end{tabular}

E. = Euseius scutalis, $P .=$ Pronomatus ubiquitous, I.D.= Inspection date and $*$ Significant at $5 \%$ level. 
Table 4. Population fluctuation of the two predatory mites Euseius scutalis (A.-H.) and Pronomatus ubiquitous (McGregor), on ten maize single hybrids at Gharbia governorate during season 2005.

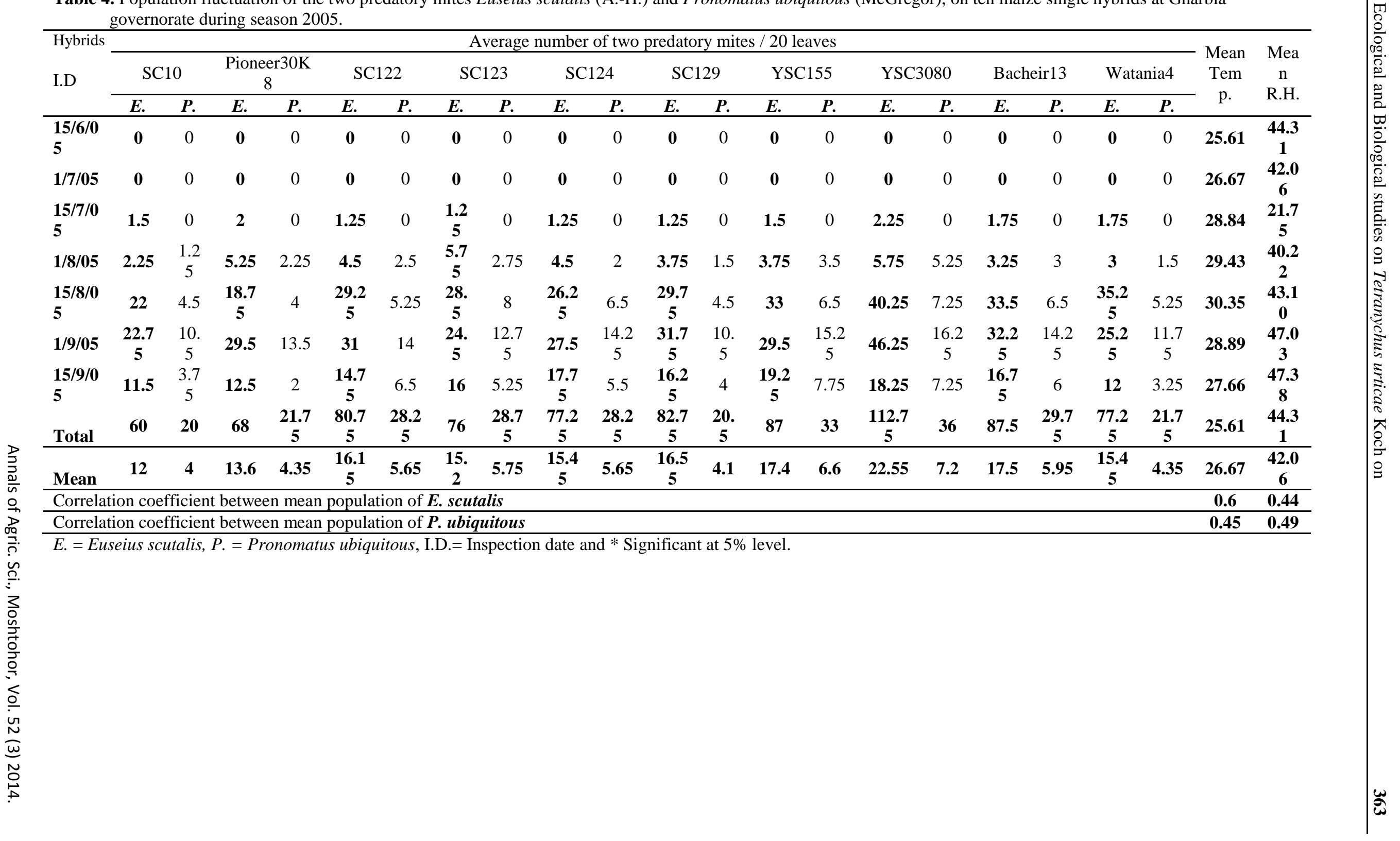


Table 5. Correlation coefficient between population fluctuation of predacious mites and its relation to T. urticae mites, on ten maize single hybrids at Gharbia governorate during season 2004.

\begin{tabular}{|c|c|c|c|c|c|c|c|c|c|c|c|c|c|c|c|}
\hline \multirow{2}{*}{$\begin{array}{l}\text { Hybrids } \\
\text { Pred. } \\
\text { Prey } \\
\end{array}$} & \multicolumn{3}{|c|}{ SC10 } & \multicolumn{3}{|c|}{ Pioneer30K8 } & \multicolumn{3}{|c|}{ SC122 } & \multicolumn{3}{|c|}{ SC123 } & \multicolumn{3}{|c|}{ SC124 } \\
\hline & $\begin{array}{c}E . \\
\text { scutalis }\end{array}$ & $\begin{array}{c}P . \\
\text { ubiquitous }\end{array}$ & $\begin{array}{l}\text { Total } \\
\text { Pred. }\end{array}$ & $\begin{array}{c}E . \\
\text { scutalis }\end{array}$ & $\begin{array}{c}P . \\
\text { ubiquitous }\end{array}$ & $\begin{array}{l}\text { Total } \\
\text { Pred. }\end{array}$ & $\begin{array}{c}E . \\
\text { scutalis }\end{array}$ & $\begin{array}{c}P . \\
\text { ubiquitous }\end{array}$ & $\begin{array}{l}\text { Total } \\
\text { Pred. }\end{array}$ & $\begin{array}{c}E . \\
\text { scutalis }\end{array}$ & $\begin{array}{c}P . \\
\text { ubiquitous }\end{array}$ & $\begin{array}{l}\text { Total } \\
\text { Pred. }\end{array}$ & $\begin{array}{c}E . \\
\text { scutalis }\end{array}$ & $\begin{array}{c}P . \\
\text { ubiquitous }\end{array}$ & $\begin{array}{l}\text { Total } \\
\text { Pred. }\end{array}$ \\
\hline T. urticae & $0.93 * *$ & $0.91 * *$ & $0.94 * *$ & 0.44 & 0.14 & 0.29 & 0.33 & 0.36 & 0.35 & 0.38 & 0.46 & 0.42 & 0.30 & 0.24 & 0.29 \\
\hline Hybrids & & SC129 & & & YSC155 & & & YSC3080 & & & Bacheir 13 & & & Watania4 & \\
\hline $\begin{array}{l}\text { Pred. } \\
\text { Prey }\end{array}$ & $\begin{array}{c}E . \\
\text { scutalis }\end{array}$ & $\begin{array}{c}P . \\
\text { ubiquitous }\end{array}$ & $\begin{array}{l}\text { Total } \\
\text { Pred. }\end{array}$ & $\begin{array}{c}E . \\
\text { scutalis }\end{array}$ & $\begin{array}{c}P . \\
\text { ubiquitous }\end{array}$ & $\begin{array}{l}\text { Total } \\
\text { Pred. }\end{array}$ & $\begin{array}{c}E . \\
\text { scutalis }\end{array}$ & $\begin{array}{c}P . \\
\text { ubiquitous }\end{array}$ & $\begin{array}{l}\text { Total } \\
\text { Pred. }\end{array}$ & $\begin{array}{c}E . \\
\text { scutalis }\end{array}$ & $\begin{array}{c}P . \\
\text { ubiquitous }\end{array}$ & $\begin{array}{l}\text { Total } \\
\text { Pred. }\end{array}$ & $\begin{array}{c}E . \\
\text { scutalis }\end{array}$ & $\begin{array}{c}P . \\
\text { ubiquitous }\end{array}$ & $\begin{array}{l}\text { Total } \\
\text { Pred. }\end{array}$ \\
\hline $\begin{array}{l}\text { T. urticae } \\
\text { motile } \\
\text { stages }\end{array}$ & 0.16 & 0.06 & 0.12 & 0.31 & 0.43 & 0.37 & 0.54 & $0.80 *$ & 0.61 & 0.54 & 0.16 & 0.34 & 0.53 & 0.47 & 0.51 \\
\hline
\end{tabular}

Pred. = Predatory mite, Phyto. $=$ Phytophagous mites.

Table 6. Correlation coefficient between population fluctuation of predacious mites and its relation to T. urticae, on ten maize single hybrids at Gharbia governorate during season 2005 .

\begin{tabular}{|c|c|c|c|c|c|c|c|c|c|c|c|c|c|c|c|}
\hline \multirow{2}{*}{$\begin{array}{l}\text { Hybrids } \\
\text { Pred. } \\
\text { Prey } \\
\end{array}$} & \multicolumn{3}{|c|}{ SC10 } & \multicolumn{3}{|c|}{ Pioneer30K8 } & \multicolumn{3}{|c|}{ SC122 } & \multicolumn{3}{|c|}{ SC123 } & \multicolumn{3}{|c|}{ SC124 } \\
\hline & $\begin{array}{c}E . \\
\text { scutalis }\end{array}$ & $\begin{array}{c}P . \\
\text { ubiquitous }\end{array}$ & $\begin{array}{l}\text { Total } \\
\text { Pred. }\end{array}$ & $\begin{array}{c}E . \\
\text { scutalis } \\
\end{array}$ & $\begin{array}{c}P . \\
\text { ubiquitous }\end{array}$ & $\begin{array}{l}\text { Total } \\
\text { Pred. }\end{array}$ & $\begin{array}{c}E . \\
\text { scutalis }\end{array}$ & $\begin{array}{c}P . \\
\text { ubiquitous }\end{array}$ & $\begin{array}{l}\text { Total } \\
\text { Pred. }\end{array}$ & $\begin{array}{c}E . \\
\text { scutalis }\end{array}$ & $\begin{array}{c}P . \\
\text { ubiquitous }\end{array}$ & $\begin{array}{l}\text { Total } \\
\text { Pred. }\end{array}$ & $\begin{array}{c}E . \\
\text { scutalis } \\
\end{array}$ & $\begin{array}{c}P . \\
\text { ubiquitous }\end{array}$ & $\begin{array}{l}\text { Total } \\
\text { Pred. }\end{array}$ \\
\hline $\begin{array}{l}\text { T. urticae } \\
\text { Motile }\end{array}$ & 0.50 & $0.76 *$ & 0.58 & 0.59 & $0.74 *$ & $0.65 *$ & 0.51 & $0.73 *$ & 0.59 & 0.38 & 0.63 & 0.46 & 0.40 & 0.64 & 0.48 \\
\hline Hybrids & & SC129 & & & YSC155 & & & YSC3080 & & & Bacheir13 & & & Watania4 & \\
\hline $\begin{array}{l}\text { Pred. } \\
\text { Prey }\end{array}$ & $\begin{array}{c}E . \\
\text { scutalis }\end{array}$ & $\begin{array}{c}P . \\
\text { ubiquitous }\end{array}$ & $\begin{array}{l}\text { Total } \\
\text { Pred. }\end{array}$ & $\begin{array}{c}E . \\
\text { scutalis }\end{array}$ & $\begin{array}{c}P . \\
\text { ubiquitous }\end{array}$ & $\begin{array}{l}\text { Total } \\
\text { Pred. }\end{array}$ & $\begin{array}{c}E . \\
\text { scutalis }\end{array}$ & $\begin{array}{c}P . \\
\text { ubiquitous }\end{array}$ & $\begin{array}{l}\text { Total } \\
\text { Pred. }\end{array}$ & $\begin{array}{c}E . \\
\text { scutalis }\end{array}$ & $\begin{array}{c}P . \\
\text { ubiquitous }\end{array}$ & $\begin{array}{l}\text { Total } \\
\text { Pred. }\end{array}$ & $\begin{array}{c}E . \\
\text { scutalis }\end{array}$ & $\begin{array}{c}P . \\
\text { ubiquitous }\end{array}$ & $\begin{array}{l}\text { Total } \\
\text { Pred. }\end{array}$ \\
\hline $\begin{array}{l}\text { T. urticae } \\
\text { motile } \\
\text { stages }\end{array}$ & 0.45 & $0.69 *$ & 0.51 & 0.35 & $0.70^{*}$ & 0.46 & 0.54 & $0.80 *$ & 0.61 & 0.47 & $0.74 *$ & 0.55 & 0.34 & $0.75 *$ & 0.46 \\
\hline
\end{tabular}

Pred. = Predatory mite, Phyto. = Phytophagous mites. 
Table 7. Evaluation of the susceptibility of different maize single hybrids to T. urticae infestation at Gharbia governorate during season 2004-2005.

Hybrids

Average number of $T$. urticae / 20 leaves

L.S.D.

\begin{tabular}{|c|c|c|c|c|c|c|c|c|c|c|c|}
\hline Season & SC10 & Pioneer30K8 & SC122 & SC123 & SC124 & SC129 & YSC155 & YSC3080 & Bacheir13 & Watania4 & ע \\
\hline 2004 & $115.54^{\mathrm{c}}$ & $179.39^{b}$ & $127.82^{\mathrm{c}}$ & $175.54^{b}$ & $172.21^{b}$ & $189.57^{b}$ & $191.21^{b}$ & $235.21^{\mathrm{a}}$ & $172.14^{b}$ & $127.25^{\mathrm{c}}$ & 22.59 \\
\hline 2005 & $118.46^{c}$ & $209.71^{b}$ & $138.29^{c}$ & $212.00^{b}$ & $208.00^{b}$ & $201.64^{b}$ & $212.79^{b}$ & $274.50^{\mathrm{a}}$ & $205.79^{b}$ & $135.21^{\mathrm{c}}$ & 25.95 \\
\hline
\end{tabular}

The means with the same letters at the same row are not significantly different at $0.05 \%$ level.

Table 8. Phytochemical components of ten single hybrid leaves and population of T. urticae at Gharbia governorate season 2005.

\begin{tabular}{|c|c|c|c|c|c|c|c|}
\hline \multirow[b]{2}{*}{ Hybrids } & \multirow{2}{*}{$\begin{array}{c}\text { Average no. of } \\
\text { motile stages/ } 20 \\
\text { leaves }\end{array}$} & \multicolumn{6}{|c|}{ Concentration of Phytochemical components } \\
\hline & & $\begin{array}{c}\mathrm{N} \\
\mathrm{mg} / \mathrm{gm}\end{array}$ & $\begin{array}{c}\mathbf{P} \\
\mathrm{mg} / \mathrm{gm}\end{array}$ & $\begin{array}{l}\mathrm{K} \\
\%\end{array}$ & $\begin{array}{c}\mathrm{Ca} \\
\mathrm{mg} / 100 \mathrm{gm}\end{array}$ & $\begin{array}{c}\text { Carbohyd. } \\
\%\end{array}$ & $\begin{array}{c}\text { Protein } \\
\%\end{array}$ \\
\hline SC10 & $118.46^{c}$ & $3.0^{d}$ & $2.5^{d}$ & $3.2^{\mathrm{a}}$ & $32.0^{\mathrm{a}}$ & $50.5^{g}$ & $11.0^{\mathrm{g}}$ \\
\hline Pioner30K8 & $209.71^{b}$ & $4.0^{a b}$ & $3.7^{\mathrm{a}}$ & $1.8^{\mathrm{f}}$ & $24.0^{h}$ & $64.3^{\mathrm{a}}$ & $12.8^{\mathrm{cd}}$ \\
\hline SC122 & $138.29^{c}$ & $3.0^{d}$ & 2.8 & $2.6^{\mathrm{c}}$ & $29.5^{c}$ & $56.3^{\mathrm{e}}$ & $11.6^{\mathrm{fg}}$ \\
\hline $\begin{array}{l}\text { SC123 } \\
\text { SC124 } \\
\text { SC129 } \\
\text { YSC155 }\end{array}$ & $\begin{array}{l}212.00^{b} \\
208.00^{b} \\
201.64^{b} \\
212.79^{b}\end{array}$ & $\begin{array}{c}3.57^{\mathrm{c}} \\
3.6^{\mathrm{c}} \\
3.78^{\mathrm{ab}} \\
3.5^{\mathrm{c}}\end{array}$ & $\begin{array}{c}3.5^{\mathrm{ab}} \\
3.0^{\mathrm{c}} \\
\mathbf{3 . 2 8}^{\mathrm{b}} \\
\mathbf{3 . 0}^{\mathrm{c}}\end{array}$ & $\begin{array}{l}2.2^{\mathrm{e}} \\
2.2^{\mathrm{e}} \\
2.4^{\mathrm{d}} \\
2.1^{\mathrm{e}}\end{array}$ & $\begin{array}{c}28.0^{\text {de }} \\
27.55^{\text {e }} \\
26.4^{\text {f }} \\
28.68^{\text {cd }}\end{array}$ & $\begin{array}{l}\mathbf{6 3 . 6}^{\mathrm{a}} \\
\mathbf{6 0 . 3 ^ { \mathrm { c } }} \\
\mathbf{5 4 . 3 ^ { \mathrm { f } }} \\
\mathbf{5 7 . 5 ^ { \mathrm { d } }}\end{array}$ & $\begin{array}{l}13.3^{\mathrm{bc}} \\
12.5^{\mathrm{de}} \\
12.7^{\mathrm{cd}} \\
12.2^{\mathrm{de}}\end{array}$ \\
\hline YSC3080 & $274.50^{a}$ & $4.2^{\mathrm{a}}$ & $3.5^{a b}$ & $1.5^{\mathrm{g}}$ & $25.0^{g}$ & $63.5^{\mathrm{a}}$ & $14.5^{\mathrm{a}}$ \\
\hline Bacheir13 & $205.79^{b}$ & $4.17^{\mathrm{a}}$ & $3.6^{\mathrm{a}}$ & $1.6^{\mathrm{g}}$ & $25.1^{\mathrm{g}}$ & $62.4^{b}$ & $13.7^{b}$ \\
\hline Watania4 & $135.21^{\mathrm{c}}$ & $2.78^{d}$ & $2.4^{d}$ & $2.8^{\mathrm{b}}$ & $30.5^{\mathrm{b}}$ & $\mathbf{5 3 . 4} 4^{\text {f }}$ & $11.68^{\text {ef }}$ \\
\hline L.S.D. & 25.95 & 0.29 & 0.27 & 0.14 & 0.95 & 1.09 & 0.58 \\
\hline $\begin{array}{l}\text { Correlation } \\
\text { population a }\end{array}$ & etween & $0.87 * *$ & $0.80 *$ & $-\mathbf{0 . 8 9} * *$ & $-0.80 *$ & $0.78 *$ & $0.90 * *$ \\
\hline
\end{tabular}

The means with the same letters at the same column are not significantly different at $0.05 \%$ level. 
Table 9. Biological aspects and life table parameters of two-spotted spider mite T. urticae at $28^{\circ} \mathrm{C}$ and $65 \%$ R.H., on different maize single hybrids.

\begin{tabular}{|c|c|c|c|c|c|c|c|c|c|c|}
\hline \multirow[b]{2}{*}{ Parameters } & \multirow[t]{2}{*}{ Hybrids } & \multicolumn{2}{|c|}{ YSC3080 } & \multicolumn{2}{|c|}{ Bacheir13 } & \multicolumn{2}{|c|}{ SC122 } & \multicolumn{2}{|c|}{ SC10 } & \multirow[t]{2}{*}{ L.S.D 0.05} \\
\hline & & 9 & $\hat{0}$ & 9 & 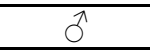 & 9 & $\hat{0}$ & $q$ & $\hat{0}$ & \\
\hline Incubation period & & $3.2 \pm 0.6^{b}$ & $2.7 \pm 0.4$ & $3.3 \pm 0.4^{b}$ & $3.1 \pm 0.3$ & $3.7 \pm 0.6^{\mathrm{ab}}$ & $3.6 \pm 0.5$ & $3.9 \pm 1.1^{\mathrm{a}}$ & $3.6 \pm 0.8$ & 0.45 \\
\hline Larva & & $2.1 \pm 0.5^{c}$ & $1.8 \pm 0.5$ & $1.8 \pm 0.3^{c}$ & $1.8 \pm 0.3$ & $2.4 \pm 0.5^{b}$ & $2.2 \pm 0.5$ & $3.5 \pm 0.5^{\mathrm{a}}$ & $3.4 \pm 0.7$ & 0.29 \\
\hline Protonymph & & $1.6 \pm 0.5^{\mathrm{a}}$ & $1.3 \pm 0.4$ & $1.5 \pm 0.5^{\mathrm{a}}$ & $1.5 \pm 0.5$ & $1.5 \pm 0.5^{\mathrm{a}}$ & $1.3 \pm 0.3$ & $1.6 \pm 0.4^{\mathrm{a}}$ & $1.6 \pm 0.4$ & 0.29 \\
\hline Deutonymph & & $1.5 \pm 0.5^{b}$ & $1.3 \pm 0.3$ & $1.8 \pm 0.4^{\mathrm{a}}$ & $1.4 \pm 0.3$ & $1.6 \pm 0.5^{\mathrm{ab}}$ & $1.5 \pm 0.3$ & $1.6 \pm 0.4^{\mathrm{ab}}$ & $1.5 \pm 0.4$ & 0.27 \\
\hline Immature stages & & $5.1 \pm 0.8^{b}$ & $4.3 \pm 0.8$ & $5.1 \pm 0.5^{b}$ & $4.7 \pm 0.6$ & $5.5 \pm 0.9^{b}$ & $5.0 \pm 0.6$ & $6.7 \pm 0.8^{\mathrm{a}}$ & $6.5 \pm 1.0$ & 0.48 \\
\hline Life cycle & & $8.3 \pm 1.1^{c}$ & $7.0 \pm 0.8$ & $8.5 \pm 0.6^{c}$ & $7.8 \pm 0.7$ & $9.2 \pm 1.1^{b}$ & $8.6 \pm 0.9$ & $10.6 \pm 1.2^{\mathrm{a}}$ & $10.1 \pm 1.1$ & 0.62 \\
\hline Generation period & & $9.8 \pm 1.3^{c}$ & & $10.0 \pm 0.7^{c}$ & & $11.1 \pm 0.3^{b}$ & & $12.7 \pm 1.4^{\mathrm{a}}$ & & 0.76 \\
\hline Pre-oviposition period & & $1.5 \pm 0.5^{b}$ & & $1.6 \pm 0.4^{b}$ & & $2.0 \pm 0.4^{\mathrm{a}}$ & & $2.1 \pm 0.6^{\mathrm{a}}$ & & 0.28 \\
\hline Oviposition period & & $9.8 \pm 2.6^{a}$ & & $7.5 \pm 1.5^{b}$ & & $6.4 \pm 1.1^{\mathrm{c}}$ & & $5.7 \pm 1.0^{c}$ & & 1.05 \\
\hline Post-oviposition period & & $1.5 \pm 0.5^{b}$ & & $1.3 \pm 0.5^{b}$ & & $1.5 \pm 0.5^{b}$ & & $1.9 \pm 0.6^{\mathrm{a}}$ & & 0.33 \\
\hline Longevity & & $12.8 \pm 2.7^{\mathrm{a}}$ & $12.0 \pm 2.6$ & $10.4 \pm 1.7^{b}$ & $9.8 \pm 1.6$ & $9.9 \pm 1.3^{b}$ & $10.1 \pm 1.4$ & $9.8 \pm 1.0^{b}$ & $9.3 \pm 1.1$ & 1.12 \\
\hline Mean fecundity (eggs/ + ) & & $44.8 \pm 3.5^{\mathrm{a}}$ & & $27.6 \pm 3.6^{b}$ & & $26.5 \pm 3.9^{b}$ & & $19.8 \pm 3.4^{c}$ & 0.8 & 2.26 \\
\hline Mean daily rate (eggs/ $q /$ day) & & $4.6 \pm 1.3^{\mathrm{a}}$ & & $3.8 \pm 0.8^{b}$ & & $4.2 \pm 1.0^{\mathrm{ab}}$ & & $3.6 \pm 1.0^{b}$ & & 0.66 \\
\hline Life span & & $21.1 \pm 2.4^{\mathrm{a}}$ & $19.0 \pm 2.6$ & $18.8 \pm 1.9^{b}$ & $17.6 \pm 1.2$ & $19.1 \pm 2.0^{b}$ & $18.7 \pm 1.3$ & $20.3 \pm 1.5^{\mathrm{a}}$ & $19.4 \pm 0.79$ & 1.23 \\
\hline Double generation (DT) ${ }^{a}$ & & 2.86 & & 3.31 & & 3.7 & & 5.09 & & \\
\hline $50 \%$ mortality ${ }^{a}$ & & 13.8 & & 13 & & 16 & & 16.1 & & \\
\hline Sex ratio (female/ total) & & 0.7 & & 0.7 & & 0.65 & & 0.6 & & \\
\hline Intrinsic rate of increases $\left(r_{m}\right)^{c}$ & & 0.242 & & 0.209 & & 0.187 & & 0.136 & & \\
\hline Finite rate of increases $(\lambda)$ & & 1.27 & & 1.23 & & 1.2 & & 1.14 & & \\
\hline Net reproductive rate $\left(R_{0}{ }^{b}\right.$ & & 18.79 & & 12.47 & & 14.42 & & 7.2 & & \\
\hline
\end{tabular}




\section{References}

Abou-Setta, M. M., Sorrell, R.W. and Childers, C.C. 1986. Life 48: a BASIC computer program to calculate life table parameters for an insect or mite species. Fla. Entomol. 69:690-697.

Afifi, A. M, El-Bishlawy, S.M and Mohmoud, H. 2013. Resistance of two Eggplant cultivars against the two-spotted spider mite; Tetranychus urticae Koch infestation, with note on its biology. Acarines, 7(2) 23-27.

Afifi, A. M., El-Laithy, A. Y., Shehata, S. A, ElSaiedy, M. A. 2010. Resistance of strawberry plants against the two-spotted spider mite, Tetranychus urticae (Acari: Tetranychidae). In: Sabelis, M.V., Bruin, J. Trends in Acarology. Proceedings of the 12th Inter. Cong. Amsterdam, The Netherlands. pp: 505-507.

Azouz, H. A. 2005. Ecological and biological studies on some mites associated with cotton and some field crops in Beni-Suef governorate. Ph.D. Thesis, Fac. Agric., Al-Azhar Univ., 181pp.

Bacon, O. G., Lyons, T. and Baskett, R.S. 1962. Effects of spider mite infestations on dent corn in California. J. Econ. Entomol. 55:823-825.

El-Halawany, A.S. and Abd El-wahed, N. 2013. Effect of temperature and host plant on developmental times and life table parameters of Tetranychus urticae Koch on persimmon Trees. (Acari: Tetranychidae). Egypt. J. Agric. Res., 91(2): 595-606.

Labanowska, B. H. 2007. Susceptibility of strawberry cultivars to the two-spotted spider mite. J. Fruit Ornam. Plant Res. 15: 133-146.
Liu, Y. H. and J. H. Tsai. 1998. Development, survivorship and reproduction temperature. International. J. Acarol., 24 (3):245- 252.

Margoli, D. C. and Kennedy, G. G. 1984. Population response of the two-spotted spider mite, Tetranychus urticae to host phenology in corn and peanut. Ent. Exp. Appl., 36(2): 193-196.

Mead, H. M., El-Kawas, H. and Desuky, W. M. 2010. Susceptibility of certain maize varieties to Tetranychus urticae Koch infestation in relation to leaf chemical contents. Acarines, 4, 25-30.

Najafabadi, S. S. M. 2012. Resistance to Tetranychus urticae Koch (Acari: Tetranychidae) in Phaseolus vulgaris L. Middle-East J. of Sci. Res. 11 (6): 690-701.

Rezaie, M., Saboori, A., Baniamerie, V. and Allahyari, H. 2013. Susceptibility of Tetranychus urticae Koch (Acari: Tetranychidae) on seven strawberry cultivars. Inter. Research J. of Appl. and Bas. Sci., 4 (9): 2455-2463.

SAS Institute, 2010. SAS Statistics and Graphics Guide, Release 9.1. SAS Institute, Cary, North . Carolina 27513, USA.

Skorupska, A. 2004. Resistance of apple cultivars to two-spotted spider mite, Tetranychus urticae Koch (Acarina: Tetranychidae). Part I. Bionomy of two-spotted spider mite on selected cultivars of apple trees. J. Plant Protection Res. 44 (1): 75-80.

Zaher, M. A. 1984. Survey and ecological studies on phytophagous, predaceous and soil mites in Egypt. I: Phytophagous mites in Egypt (Nile valley and Delta). PI 480 Prog. USA Project No. EG. ARS, 30. Grant. No, FG, Eg., 81. 228pp. 


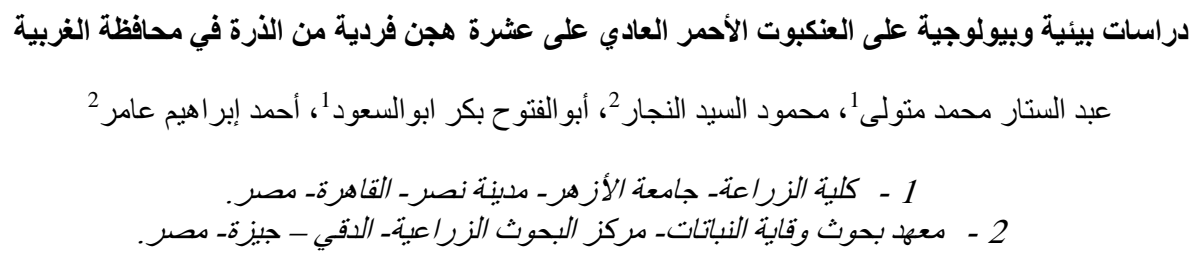

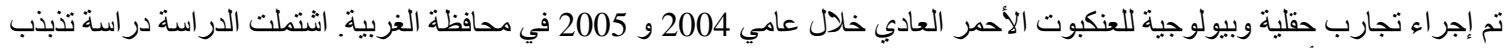

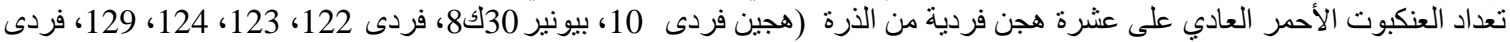

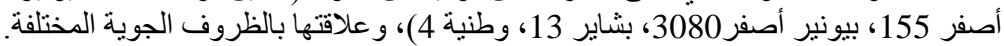

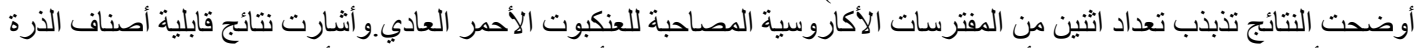

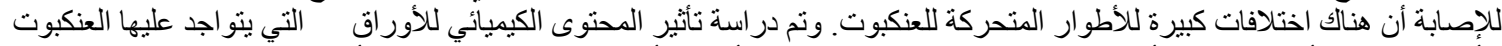

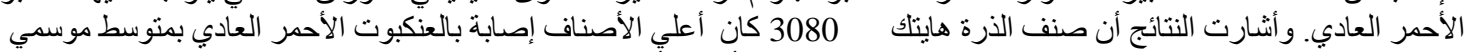

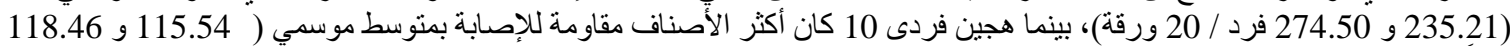

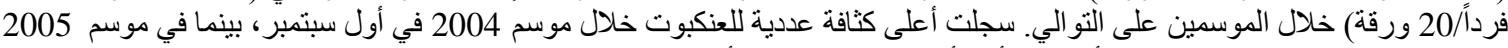

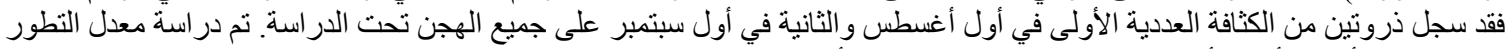

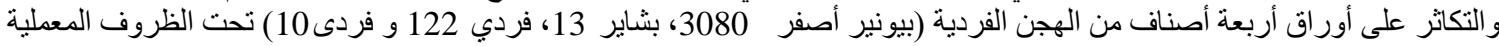

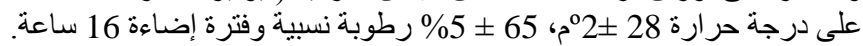
سجلت أطول فترة للتطور العنكبوت الأحمر العادي على هجين فردى 10 (6.7 10 (6.7 يوم) يليه هجين أصفر ( 5.5يوم) ثم بشاير 13و بيونير

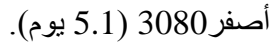

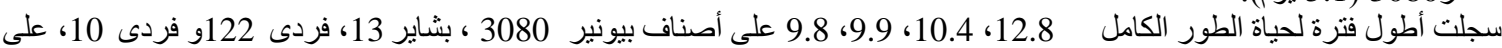

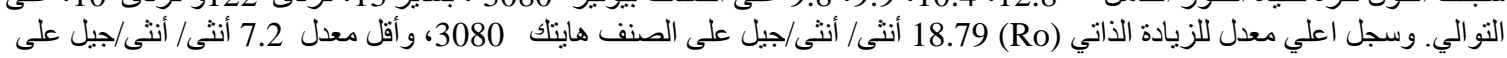

